ВПЛИВ ОСВІТНЬОГО СЕРЕДОВИЩА ВИЩОЇ ШКОЛИ НА ФОРМУВАННЯ ГОТОВНОСТІ МАЙБУТНІХ УЧИТЕЛІВ ДО ІННОВАЦІЙНОÏ ВИХОВНОÏ ДІЯЛЬНОСТІ

\title{
THE INFLUENCE OF THE EDUCATIONAL ENVIRONMENT OF HIGHER EDUCATION ON FORMING THE READINESS OF FUTURE TEACHERS FOR INNOVATIVE EDUCATIONAL ACTIVITIES
}

Стаття присвячена одній з актуальних проблем підготовки майбутніх учителів - розкриттю впливу інноваційного освітнього середовища вищої школи на формування готовності майбутніх учителів до інноваційної виховної діяльності. Зокрема, розкрито сутність понять «інноваційне освітнє середовище», «інноваційна виховна діяльність», «виховний прочес у ЗВО». Зазначено, що інноваційне освітнє середовище базується на загальнолюдських і національних цінностях, духовній культурі, гуманізації, естетизації; йому властивий гуманізм його суб'єктів, толерантні відношення і партнерське співробітництво між ними, взаємна вимогливість i креативність. Зроблено висновок, що виховне середовище повинно мати творчу спрямованість, спиратися на внутрішні і зовнішні процеси його організації, створювати передумови для самореалізації, саморозвитку особистості і підвищення рівня ії моральної вихованості. У статті інноваційне виховне середовище вищої школи розглядається як система об'єктивних зовнішніх впливів $і$ духовно-матеріальних умов формування особистості в закладі вищої освіти, що відкриває нові можливості для організації виховної роботи, самореалізації, самовдосконалення студентів, розвитку їхніх особистісних і профресійних якостей. Висвітлено основні принципи виховання у ЗВО та напрями створення інноваційного виховного середовища у вищій школі. Зазначено, що створення у ЗВО інноваційного освітнього середовища передбачає вдосконалення виховної роботи в системі вищоі освіти, а саме: модернізацію змісту виховного процесу, наповнення його інноваціями з урахуванням культурно-історичного надбання й традииій українського народу; впровадження новітніх підходів, виховних систем, фрорм і методів виховання; врахування потреб розвитку особистості, розкриття їі талантів і здібностей; урахування вітчизняного і зарубіжного досвіду розроблення теоретико-методологічних аспектів національної системи виховання тощо. Обрунтовано, що важливими елементами інноваційного виховного середовища є використання виховного потенціалу навчальних предметів у прочесі пізнання; активна творча і комунікативна діяльність, робота студентського самоврядування, створення позитивного мікроклімату в студентській аудиторії, позааудиторна робота.

Ключові слова: інноваційне освітнє середовище, вища школа, готовність майбутніх учителів, інновачійна виховна діяльність, виховний процес у закладах вищої освіти.
The article is devoted to one of the urgent problems of training future teachers - to reveal the influence of the innovative educational environment of higher education on the formation of future teachers' readiness for innovative educational activities. In particular, the essence of the concepts «innovative educational environment», «innovative educational activity», «educational process in the HEI» is revealed. It is noted that the innovative educational environment is based on universal and national values, spiritual culture, humanization, aestheticization; it is characterized by the humanism of its subjects, tolerant relations and partnership cooperation between them, mutual exactingness and creativity. It is concluded that the educational environment should have a creative focus, rely on the internal and external processes of its organization, create the preconditions for selfrealization, self-development of the individual and increase the level of his moral education. In the article, the innovative educational environment of higher education is considered as a system of objective external influences and spiritual and material conditions for the formation of a personality in a higher education institution, opens up new opportunities for organizing educational work, self-realization, selfimprovement of students, and the development of their personal and professional qualities. The main principles of education in the HEI and the directions of creating an innovative educational environment in higher education are highlighted. It is noted that the creation of an innovative educational environment in the $\mathrm{HEI}$ presupposes the improvement of educational work in the higher education system, namely: the modernization of the content of the educational process, filling it with innovations, taking into account the cultural and historical heritage and traditions of the Ukrainian people; introduction of new approaches, educational systems, forms and methods of education; taking into account the needs of personality development, disclosure of her talents and abilities; taking into account domestic and foreign experience in the development of theoretical and methodological aspects of the education system and the like. It has been substantiated that important elements of an innovative educational environment are: the use of the educational potential of academic subjects in the process of cognition; active creative and communicative activities, the work of student government, the creation of a positive microclimate in the student audience, extracurricular work.

Key words: innovative educational environment, higher school, readiness of future teachers, innovative educational activity, educational process in higher education institutions. 
Постановка проблеми у загальному вигляді. Сьогодні в сучасній педагогіці активізувалися пошуки в дослідженнях освітнього середовища закладу вищої освіти, в якому фрормується готовність майбутніх учителів до інноваційної виховної діяльності, реалізуються механізми їх саморозвитку і самовдосконалення. Гіпотеза, що будь-яка зміна освітнього середовища у контексті впровадження інновацій призводить до змін у людині, не викликає сумнівів. Освітнє середовище мінливе передбачає постійні зміни - інновації. Інноваційне освітнє середовище являє собою континуум, що розвивається і складається із просторово-тимчасових, соціально-культурних, практично-діяльнісних, комунікативно-інфрормаційних й інших фракторів. Саме тому вважаємо актуальним питання взаємодії процесу формування готовності майбутніх учителів до інноваційної виховної діяльності й розвитку інноваційного освітнього середовища закладу вищої освіти.

Аналіз останніх досліджень і публікацій. Різні аспекти фрормування інноваційного освітнього середовища висвітлені у працях таких науковців, як Л. Ващенко, А. Каташов, М. Опачко, Г. Розлуцька, Н. Ткачук, О. Цюняк, О. Шапран, Ю. Шапран та ін. Проблема підготовки викладача до виховної роботи досліджується у наукових працях С. Бреуса, О. Дубасенюк, В. Сластьоніна, Г. Троцко та ін. Тенденції розвитку вищої освіти загалом і їі виховні аспекти висвітлюються у дослідженнях Л. Герасіної, О. Кузя, В. Курила, Н. Лазоренко, В. Лугового, В. Таточенко, А. Шипко та ін. Сучасний процес виховання у вищій школі в Україні та за її межами розглядали І. Бех, Р. Кнушевицька, Я. Колібабюк, Л. Москальова, Д. Пащенко, О. Романовський, Н. Селіванова, І. Тишик та ін.

Виділення невирішених раніше частин загальної проблеми. Водночас існує низка суперечностей, що негативно позначаються на кінцевому результаті виховної роботи у закладах вищої освіти, зокрема: між традиційними підходами до підготовки майбутніх учителів до здійснення професійно орієнтованої виховної роботи у 3ВО та потребою сучасної школи у педагогах-професіоналах; між сучасними вимогами до готовності студентів вищої школи до ефективної виховної діяльності та недостатньою їх теоретичною і практичною підготовкою; між необхідністю використання у виховній діяльності нових форм, методів і технологій та їх застосуванням у практиці роботи вищої школи тощо. Сьогодні нерозв'язаними залишаються проблеми визначення особливостей професійного середовища сучасного закладу вищої освіти, специфріки теоретичної і практичної підготовки майбутніх учителів у мінливих умовах реформування системи професійно-педагогічної освіти.

Мета статті - розкриття впливу інноваційного освітнього середовища вищої школи на фрорму- вання готовності майбутніх учителів до інноваційної виховної діяльності.

Виклад основного матеріалу. Для вирішення означених завдань з'ясуємо понятійно-змістові аспекти цієї проблематики. Погоджуємося 3 О. Керницьким, що середовище у науковій літературі розглядається як простір, місце; сукупність умов, фракторів, впливів, можливостей розвитку суб'єктів; виховний фрактор суспільства, соціального інституту, колективу; фрактор освіти й розвитку особистості. Найчастіше визначення освітнього середовища дається через його розуміння як частини освітнього простору, який безпосередньо оточує суб'єктів освітнього процесу й включає їх у себе. У тлумаченні цього автора відмінність між освітнім простором і освітнім середовищем глибше, тому що освітнє середовище містить у собі й таку характеристику матерії, як час, тобто освітнє середовище, на відміну від стійких просторових структур, має довжину й мінливість у часі. Поняття простору фріксує увагу дослідників на впорядкованій безлічі людиностворюючих систем, тоді як освітнє середовище описує різноманітність як безпосередньо відносних до суб'єкта, так і нейтральних для нього фракторів [4]. Отже, освітнє середовище є більш індивідуальним для кожної людини, що фрормується і розвивається під впливом певних чинників. У організованому просторі сучасного ЗВО майбутній учитель знаходить своє середовище, свого роду індивідуальну нішу для діяльнісних проявів.

Зупинимося на визначенні сутнісних характеристик цього поняття. У сучасних теоретичних дослідженнях, як зазначає Н. Ткачук, існують такі тлумачення поняття «інноваційне освітнє середовище», як: сукупність духовно-матеріальних умов функціонування закладу освіти, що забезпечують саморозвиток вільної і активної особистості, реалізацію творчого потенціалу дитини; виступає фрункціональним і просторовим об'єднанням суб'єктів освіти; характеристиками його $€$ здатність до самовідтворення й самооновлення відповідно до потенційних можливостей усіх складових елементів цього середовища (А. Каташов); комплекс взаємопов'язаних умов, які забезпечують освіту людини, фрормування особистості педагога 3 інноваційно-творчим мисленням, його професійну компетентність (Н. Разіна); педагогічно доцільно організований простір життєдіяльності, який сприяє розвитку інноваційного ресурсу особистості; інтегрований засіб накопичення і реалізації інноваційного потенціалу навчального закладу (О. Шапран). Зокрема, досліджуючи характеристики інноваційного освітнього середовища, вчена Н. Ткачук робить висновок, що воно (середовище) може виступати ефективним засобом розвитку профресійної компетентності педагогів й одночасно потужно впливати на професійну 
ідентичність педагогічного колективу загалом, виконувати завдання розвитку закладу освіти [7] О. Цюняк вважає, що інноваційне освітнє середовище - це система педагогічних умов особистісного та професійного розвитку особистості, яка включає територію, в межах якої діють правила інноваційної діяльності та новітні ідеї, оригінальні педагогічні технології, які застосовуються у професійній підготовці майбутніх магістрів початкової освіти та сприяють удосконаленню їхньої фрахової компетентності [8, с. 177]. Г. Розлуцька і М. Опачко роблять висновки, що інноваційне освітнє середовище здійснює позитивний вплив на підготовку вчительських кадрів і $€$ необхідним для профресійної підготовки вчителів. Необхідною умовою для реального підвищення якості підготовки майбутніх учителів, на думку цих науковців, є освіта в умовах наближених до реального соціокультурного простору. Інноваційне середовище освітнього закладу здатне впливати на особистісний та професійний розвиток вчителя і викликати інтерес до активного творчого педагогічного пошуку [6].

Отже, підсумовуючи відомі визначення цієї дефініції можна стверджувати, що науковці тлумачать інноваційне освітнє середовище як комплекс духовно-матеріальних умов фрункціонування закладу освіти у педагогічно доцільному і організованому просторі життєдіяльності, що впливають на особистісний і професійний розвиток особистості.

Відповідно до особливостей діяльності інноваційних закладів освіти А. Каташов визначає основні вимоги до інноваційного освітнього середовища сучасного ЗВО, в якому студент: абсолютна цінність, особистість, і йому надається можливість бути собою; реалізує своє право на освіту і всебічний духовний розвиток і саморозвиток відповідно до своїх потреб, здібностей і можливостей; викладач розвиває свої професійні й особистісні якості, духовну культуру, організовує навчально-виховну діяльність, виходячи з принципу природо- і культуровідповідності, гуманізації, естетизації на основі взаємодії цінностей; керівник забезпечує оптимістичний дух діяльності студента і викладача; колектив працює у творчому пошуковому режимі на основі діалогу культур; присутні гуманні, толерантні відношення партнерського співробітництва; взаємна вимогливість, повага, довіра й атмоссрера спільної радості успіху як основа життєдіяльності колективу [3, с. 7]. Ураховуючи ці вимоги можна зробити висновок, що інноваційне освітнє середовище базується на загальнолюдських і національних цінностях, духовній культурі, гуманізації, естетизації; йому властивий гуманізм його суб'єктів, толерантні відношення і партнерське співробітництво між ними, взаємна вимогливість і креативність. Усі ці прояви мають комплексний характер, який фрормується у процесі виховних впливів. Отже, можна говорити про наявність інноваційного виховного освітнього середовища.

Такий тип освітнього середовища педагогічного університету виділяють Ю. Шапран і О. Шапран у диференціації видів середовища: 1) за впровадженням нововведень (традиційне і творчо-інноваційне); 2) за видами діяльності (ігрове, навчальне, профресійне, комунікативне); 3) за особливостями оточення (природне, соціальне, інформаційноосвітнє, віртуальне); 4) за специфрікою впливу на особистість (здоров'язбережувальне, розвивальне, виховне і рефлексивне). Для виховного освітнього середовища, на думку цих вчених, характерне орормування духовних, естетичних, етичних уявлень, поглядів, переконань, системи ідеалів, трансорормації ціннісних орієнтацій сучасного суспільства в особистісні світоглядні позиції, фрормування моральних і професійних якостей $[9$, c. 7$]$.

Отже, виховне освітнє середовище виокремлюється як різновид освітнього середовища за такою ознакою, як специфріка впливу на особистість із характерними для нього ознаками. Професійна підготовка майбутнього вчителя відбувається в умовах освітнього середовища закладу вищої освіти, де фрормуються його вміння і навички не лише навчальної, а й виховної діяльності з вихованцями. А. Шевченко виховне середовище визначає як подієве наповнення життєдіяльності особистості 3 оптимальним використанням природного і соціального оточення, що створює передумови для їі самореалізації, саморозвитку, розкриття творчого потенціалу, підвищення рівня моральної вихованості [10, с. 7]. О. Жаровська зауважує, що виховне середовище створюється всередині педагогічної дійсності завдяки спеціально організованій діяльності. Створення виховного середовища передбачає внутрішні процеси, пов'язані з вибором пріоритетів педагогічної діяльності, і зовнішні, що передбачають освоєння спільнотою вихованців та дорослих оточуючого середовища [2, с. 64]. Таким чином, виховне середовище повинно мати творчу спрямованість, спиратися на внутрішні і зовнішні процеси його організації, створювати передумови для самореалізації, саморозвитку особистості і підвищення рівня ії̈ моральної вихованості.

У нашій статті інноваційне виховне середовище вищої школи розглядаємо як систему об'єктивних зовнішніх впливів і духовно-матеріальних умов фрормування особистості в закладі вищої освіти, що відкриває нові можливості для організації виховної роботи, самореалізації, самовдосконалення студентів, розвитку їх особистісних і професійних якостей.

Зробимо спробу охарактеризувати інноваційне виховне середовище 3ВО, його позитивні впливи 
на фрормування готовності майбутніх учителів до інноваційної виховної діяльності в школі. Сучасний період розвитку української вищої школи характеризується соціальними змінами, що охоплюють усі сорери людського життя та обумовлені необхідністю приведення виховного впливу у відповідність до нової системи цінностей і соціальних нормативів, що визначають духовний розвиток молоді. Виховна робота є важливою складовою сучасної національної системи освіти. У Законах України «Про освіту» (2017), «Про вищу освіту» (2014), Національній доктрині розвитку освіти (2002), Концепції національного виховання студентської молоді (2009), Концепції національно-патріотичного виховання дітей і молоді (2015), Концепції розвитку громадянської освіти в Україні (2018), Стратегії розвитку вищої освіти в Україні на 2021-2031 роки та інших нормативних документах акцентується увага на необхідності формування у вихованців поваги до національних і загальнолюдських цінностей, правової та політичної культури, критичності й самокритичності, уміння приймати самостійні рішення та відповідати за їх реалізацію. За таких умов зростає роль сучасного вчителя у суспільстві, акцентується увага на розширенні його фрункцій щодо освітніх завдань, змісту та технологій професійної підготовки майбутніх педагогів. Особлива роль у вирішенні цих важливих завдань відводиться підготовці майбутніх учителів до виховної роботи у вищій школі. Виховна робота у ЗВО потребує впровадження нової концепції виховної роботи, яка має стати основою підготовки студентської молоді до творчої життєдіяльності в нових соціально-культурних умовах, фрормування свідомої особистості громадянина України - самостійної, активної й інніціативної.

Необхідність удосконалення виховного середовища у 3ВО, пошук нових його фрорм пов'язані 3 кризою духовності, яка виникла внаслідок економічної нестабільності, соціальної незахищеності сучасної молоді, відсутності дієвих законів, нормативних актів із питань правових відносин студентської молоді і суспільства. В організації виховної роботи зі студентами необхідно враховувати, що заклад вищої освіти як соціальний інститут суспільства має притаманні специфічні ознаки (скерованість на виконання соціального замовлення суспільства; підпорядкованість суспільним потребам й керованість на державному та локальному рівнях; єдність, наступність і послідовність виховних впливів освітнього процесу та позааудиторної виховної роботи).

У сучасних дослідженнях науковців (Н. Зеленкова, Л. Кандрашова, Т. Коломієць, О. Лаврентьєва, А. Марушкевич, Т. Осипова, І. Піонтківська В. Тернопільська та ін.) поняття «виховна робота»трактується по-різному: як засіб виховання у системі організованих цілеспрямованих позааудиторних занять; процес організації масових і групових фрорм роботи; організація різних видів діяльності (пізнавальної, трудової, естетичної, спортивної тощо); фрорми організації відпочинку молоді (гурткова, туристична і краєзнавча, фрізкультурно-спортивна робота); система виховних заходів тощо. Виховна робота у ЗВО спрямована на особистісно орієнтовану педагогічну взаємодію суб'єктів виховання, метою і мірою ефективності якої $€$ особистісний і професійний розвиток майбутнього вчителя, фрормування у нього важливих рис громадянина України. Позааудиторна виховна робота $€$ підсистемою виховної роботи у ЗВО, зміст і організаційні форми якої зумовлені специфікою професійної підготовки майбутнього фахівця. Позааудиторній виховній роботі притаманні такі сутнісні характеристики, як: цілісність та безперервність; цілеспрямованість виховного впливу; творчий характер взаємодії учасників виховного процесу; наявність об'єктивних (соціальні, матеріально-технічні) та суб'єктивних умов ії організації (знання, вміння та навички суб'єктів виховання, позитивна мотивація спільної діяльності).

Процес виховання у ЗВО - система виховних заходів, спрямованих на формування всебічно розвиненої, активної й ініціативної особистості. Наголошуємо, що соціальні суб'єкти можуть самореалізуватися як особистості лише в системній взаємодії в межах освітнього простору. Під час аналізу системи виховної роботи у закладах вищої освіти варто виходити з розуміння системи як певної впорядкованої сукупності елементів, взаємопов'язаних між собою принципами, що, у свою чергу, утворюють систему та забезпечують єдність дій у процесі реалізації головної мети та завдань виховання. Тому лише за умов безперервної освіти стратегічною метою системи виховання у сучасному закладі вищої освіти є підготовка професійно й культурно орієнтованої особистості, яка відрізняється здатністю до профресійної, інтелектуальної та соціальної творчості, усвідомленням необхідності навчання та самовдосконалення протягом усього життя. Основними завданнями сучасної системи виховання в закладах вищої освіти в умовах безперервної освіти є: розробка теоретичних засад та практичних заходів, що забезпечують наступність усіх суб'єктів освітнього процесу в досягненні цілей сучасної системи освіти; створення відповідного культурно-освітнього середовища; фрормування кадрового потенціалу, створення та вдосконалення системи виховання майбутніх учителів.

Основні принципи виховання у ЗВО: суб'єктсуб'єктний характер взаємодії між учасниками освітнього процесу на основі партнерства; самоцінність особистості у визначенні цілей виховання; індивідуальна спрямованість виховних впливів; повага та довіра до особистості й вимогливість до неї; єдність свободи вибору й відповідальності; єдність прав і обов'язків особистості; комплексність виховних впливів, зв'язок теорії з практикою. 
Серед основних напрямів виховної діяльності 3 ВО виокремлюємо такі, як фрормування світогляду та ціннісної свідомості особистості; демократизація виховання, заснована на принципах педагогіки партнерства; формування духовності майбутніх фрахівців; формування патріотизму, толерантності, індивідуальності, конкурентоспроможності; самостійності; цілеспрямованості тощо [5, с. 49].

Основними напрямами створення інноваційного виховного середовища у вищій школі вважаємо такі: планування організаційно-виховної роботи серед майбутніх учителів на засадах системно-цільового підходу; виділення організаційної структури управління вихованням студентів та фрункціональних обов'язків безпосередніх учасників і підрозділів управління; наукове обґрунтування системи управління виховним процесом у новій моделі вищої освіти в XXI столітті; удосконалення традиційної структури служби управління на всіх рівнях від академічної групи до ректора закладу вищої освіти; фрормування і забезпечення національної спрямованості виховного процесу у вищій школі, тісного зв'язку з ідеалами, традиціями й іншими соціально значущими надбаннями української і світової культури; організацію і надання систематичної допомоги радам студентського самоврядування, студентським деканатам, наставникам академічних груп в організації позаудиторної роботи з боку ректорату, деканатів фракультетів, відповідних структурних підрозділів закладів вищої освіти; організацію і забезпечення здорового способу життя майбутніх учителів та навчання їх валеологічної культури в системі виховної роботи гуртків, секцій, груп тощо; проведення належної науково-методичної роботи організаторами виховного процесу з проблем позааудиторної діяльності, які б відповідали інтересам і нахилам студентів; проведення виховних заходів щодо організації відпочинку, дозвілля й попередження правопорушень серед студентської молоді; розвиток ініціативи і самодіяльності майбутніх учителів, залучення їх до активної участі в громадському житті 3 опорою на діяльність молодіжних студентських громадських організацій тощо.

Вважаємо, що виховне освітнє середовище педагогічного університету відрізняється сполученням різних складників: профресійно орієнтованих, що визначає вимоги до організації виховної діяльності, й особистісно розвиваючих, які передбачають наявність моральних якостей вихователів і вихованців (доброзичливості, гуманізму, толерантності, чуйності тощо). Важливу роль у конструюванні соціокультурного виховного середовища педагогічного університету відіграє комунікативна взаємодія між викладачами і студентами як суб'єктами освітнього процесу вищої школи, що висуває до процесу виховання як комунікативної взаємодії певні вимоги до всіх суб'єктів навчально-виховного процесу, змінює ідеальний образ сучасного викладача, уявлення про фрорми й методи його взаємодії зі студентами, їхні базові характеристики.

Комунікативна взаємодія як основний виховний механізм базується в університеті на педагогіці партнерства - суб'єкт-суб'єктній взаємодії викладача та студента, що характеризується взаєморозумінням, підтримкою, гуманізмом у стосунках. Однак, нині як у студентів, так і у викладачів не сорормовані потреби у такій взаємодії. Домінуючими напрямами роботи, за якими студенти сьогодні готові взаємодіяти з викладачами, залишається навчальна і наукова робота. Найменш комунікативні зв'язки між студентами і викладачами виникають у позааудиторній роботі, а також в індивідуальній роботі, де потрібно вирішувати особистісні проблеми та проводити виховну діяльність з урахуванням ступеня розвитку індивідуальних якостей майбутніх учителів.

Зазначимо, що, незважаючи на багатовимірні можливості педагогіки партнерства, існують й окремі проблеми, пов'язані з її впровадженням у системі вищої освіти України загалом i, зокрема, окремих ЗВО. Насамперед це проблеми, пов'язані з відсутністю цілісної концепції виховної роботи у вищій школі; проблеми, пов'язані із індивідуальною стратегією навчання, домінантою якого є власна відповідальність студентів за результати своєї праці; проблеми організації спільної творчої роботи студентів та викладачів, а також проблеми партнерських доброзичливих відносин, постійної комунікативної взаємодії між викладачами і майбутніми вчителями.

Виховання й навчання у процесі підготовки майбутнього вчителя в університеті спрямовуються на формування особистісної культури студента, організацію його діяльності в умовах гуманізації виховання, гуманітаризації освіти й підвищення загальної культури педагогічного процесу. Показниками високої культури виховного процесу є: орієнтація на фрормування системи органічно пов'язаних внутрішніх якостей особистості; відповідність цільових програм виховання науково обґрунтованій моделі фахівця; участь студента й студентських організацій у виховному процесі; органічний зв'язок основних напрямів виховання, духовно-психологічна і морально-етична насиченість виховного процесу; зв'язок етапів виховного процесу, забезпеченість наступності, послідовності, оперативності впливу; систематичність проведення виховних заходів і структурна упорядкованість організаційних фрорм і ланок; органічний зв'язок національного виховання 3 навчальною, організаційною, науковою роботою кафедри; зворотній зв'язок у вихованні (знання та врахування індивідуальних особливостей студентів, рівня їх підготовленості до реалізації професійних і соціальних ффункцій), урахування думок про якість навчально-виховного процесу; оволодіння сучасними методами й засобами виховного впливу тощо. 
Значну увагу у контексті підготовки майбутніх учителів до інноваційної виховної діяльності варто приділяти застосуванню виховного потенціалу навчальних дисциплін, які фрормують фрілософрсько-світоглядну позицію, науковий досвід, пізнавальну активність і культуру розумової праці, навички самоврядування, соціальної активності і соціальної відповідальності, політичну культуру студентів; виховують почуття любові до Батьківщини і свого народу, фрормують правосвідомість; сприяють виробленню свідомого позитивного ставлення до праці, естетичної культури і фрізичного вдосконалення [1].

Процес становлення вищої освіти безпосередньо пов'язаний з необхідністю вирішення проблем забезпечення професійного, компетентного управління виховною роботою студентів у ЗВО. У цьому контексті своєчасне і актуальне завдання, яке стоїть перед вищою школою - створення студентського самоврядування з метою підвищення соціальної відповідальності молоді, рівня самостійності і широкого залучення до життя вишу та розкриття їхнього творчого потенціалу. Тому значна увага повинна надаватися студентському самоврядуванню, а саме: визначенню його ролі й фрункцій у вищій школі; вибору студентів-лідерів, які можуть очолити органи студентського самоврядування; з'ясуванню фрорм і методів роботи студентського самоврядування у цілісному процесі підготовки майбутнього педагога. Воно покликане виховувати лідерів, фрормувати національну еліту, молоду генерацію, здатну до ефективної виховної діяльності. Важливим завданням студентського самоврядування $є$ розвиток національної свідомості, а також залучення студентства до реалізації провідних національних ідей. Сучасні студентські організації можуть реалізовувати свої права, у першу чергу, в сорері діяльності самих студентів: академічному навчанні, підвищенні його ефективності та самоосвіти; науково-дослідній роботі; культурно-освітній діяльності й організації дозвілля, суспільно-корисній праці; самоврядуванні у студентській академічній групі й гуртожитках, утвердженні в студентському середовищі здорового духовного та культурного способу життя тощо.

Висновки. Отже, створення у ЗВО інноваційного освітнього середовища передбачає вдосконалення виховної роботи в системі вищої освіти, а саме: модернізацію змісту виховного процесу, наповнення його інноваціями з урахуванням культурно-історичного надбання й традицій українського народу; впровадження новітніх підходів, виховних систем, форм і методів виховання; врахування потреб розвитку особистості, розкриття їі талантів і здібностей; урахування вітчизняного і зарубіжного досвіду розробки теоретико-методологічних аспектів національної системи виховання тощо. Таким чином, важливими елементами інноваційного виховного середовища стають: використання виховного потенціалу навчальних предметів у процесі пізнання; активна творча і комунікативна діяльність, робота студентського самовря- дування, створення позитивного мікроклімату в студентській аудиторії, позааудиторна робота. Центром інноваційного виховного середовища у ЗВО стає майбутній учитель і шлях його становлення як профресіонала. Виховне інноваційне середовище при цьому характеризується: креативністю її суб'єктів, інтенсивністю взаємодії та рівнем емоційних переживань у процесі різних видів діяльності; багатовимірністю і соціальною обумовленістю різних виховних впливів. Перспективою подальших розвідок може бути дослідження проблем вивчення та розповсюдження зарубіжного досвіду формування готовності майбутніх учителів до інноваційної виховної діяльності в освітньому середовищі вищої школи.

\section{БІБЛІОГРАФІЧНИЙ СПИСОК:}

1. Вітвицька С.С. Основи педагогіки вищої школи: підручник за модульно-рейтинговою системою навчання. [2-ге вид.]. Київ : Центр навчальної літератури, 2011. 384 с.

2. Жаровська О.П. Освітньо-виховне середовище педагогічного університету як засіб патріотичного виховання майбутніх педагогів. Педагогічна освіта: теорія і практика. Серія: Психологія. Педагогіка. 2016. № 26. C. 63-67.

3. Каташов А.І. Педагогічні основи розвитку інноваційного освітнього середовища сучасного ліцею: автореф. дис. на здобуття наук. ступеня кандидата пед. наук : 13.00.01 / Луган. держ. пед. ун-т ім. Т. Шевченка. Луганськ, 2001. 20 с.

4. Керницький О.М. Освітнє середовище вищого навчального закладу як педагогічний феномен. Проблеми інженерно-педагогічної освіти. 2013. № 38-39. С. 43-50.

5. Короденко М. Орієнтири виховної роботи в сучасному ВН3: нарада проректорів 3 виховної роботи ВН3 3-4 рівнів акредитації. Освіта України. 2008. № 29-30(913). С. 49-61.

6. Розлуцька Г.М., Опачко М.В. Формування інноваційного освітнього середовища під час підготовки сучасного вчителя. Електронний зб. наукових праць Запорізького обл. ін-ту післядипломної педагогічної освіти. 2013. Вип. 4 (14). URL: http://www. zoippo.zp.ua/pages/el_gurnal/pages/vip14.html

7. Ткачук Н. Інноваційне освітнє середовище як умова розвитку профресійної компетентності педагогів. Науковий вісник Східноєвропейського національного університету імені Лесі Українки. Серія Педагогічні науки. 2015. № 1 (302). С. 124-129.

8. Цюняк О.П. Інноваційне освітнє середовище як чинник професійного становлення майбутніх магістрів початкової освіти. Теорія і методика професійної освіти. 2019. № 14. Т. 1. С. 175-178.

9. Шапран Ю.П., Шапран О.І. Типологія освітнього середовища в умовах компетентнісно-зорієнтованої педагогічної освіти. Педагогічна освіта: теорія і практика. Серія: Психологія. Педагогіка. 2015. № 23. C. 4-10.

10. Шевченко А.Ф. Формування готовності майбутнього вчителя до діяльності в умовах тимчасового виховного середовища : автореф. дис. ... канд. пед. наук: 13.00.04 / Нац. пед. ун-т імені М. П. Драгоманова. Київ, 2009. 38 с. 